\title{
O DUPLO GRAU DE JURISDIÇÃO NA AÇÃO PENAL 470/MG: Considerações à Luz do Controle de Convencionalidade
}

\begin{abstract}
Bruno Queiroz Oliveira
Doutor em Direito Constitucional pela Unifor. Mestre em Direito Público pela Universidade Federal do Ceará. Graduado em Direito pela Universidade Federal do Maranhão. Advogado criminalista. Professor de Direito Penal no curso de Direito da Unichristus. Presidente da Comissão de Estudos Penais da OAB/CE. brunoroz@bol.com.br
\end{abstract}

Recebido em: 22/2/2016

Revisões requeridas em: 15/12/2016

Aceito em: 19/12/2016

\section{Resumo}

Aborda a interpretação dada ao duplo grau de jurisdição no julgamento da ação penal 470/ MG, mais conhecida como "Caso Mensalão". 0 objetivo da pesquisa consiste em analisar o teor do acórdão na referida ação penal e sua compatibilidade ao Pacto de São José da Costa Rica, na perspectiva do controle de convencionalidade e da relevância dos tratados de direitos humanos no constitucionalismo contemporâneo. Utilizar-se-á o método hipotético-dedutivo, com auxílio do procedimento comparativo, uma vez que o âmbito do estudo será 0 Direito brasileiro, fazendo uma análise na jurisprudência. Conclui-se que o entendimento firmado no julgamento da Ação Penal n. 470/MG acerca do pedido de desmembramento do feito em relação aos réus que não tinham foro por prerrogativa de função entra em choque com a garantia do duplo grau de jurisdição, definitivamente reconhecida no Pacto de São José da Costa Rica.

\section{Palavras-chave}

Duplo grau de jurisdição. Caso Mensalão. Devido processo legal. Garantia constitucional.

\section{THE DOUBLE DEGREE OF JURISDICTION IN THE CRIMINAL ACTION 470/MG: CONSIDERATIONS IN THE LIGHT OF THE CONTROL OF CONVENTIONALITY}

\section{Abstract}

This article discusses the interpretation given to the double degree of jurisdiction in the trial of criminal action/470 MG, better known as "Mensalão. The goal of this research is to analyze the content of the judgment in the criminal action and its compatibility to the Pact of San José of Costa Rica, in the perspective of the control of conventionality and the relevance of human rights treaties in contemporary constitutionalism. Use the hypothetical-deductive 
method, with the aid of comparative procedure, since the scope of the study will be the Brazilian law, doing an analysis in jurisprudence. It is concluded that the understanding reached at the trial the Prosecution 470/MG about the dismemberment of the request made in relation to defendants who had no venue for function prerogative comes into collision with the guarantee of the double degree of jurisdiction, definitely recognized in the Pact of San José of Costa Rica.

\section{Keywords}

Double degree of jurisdiction. Mensalão Case. Due process of law. Constitutional guarantee.

\section{Sumário}

1 Introdução. 20 Duplo Grau de Jurisdição como Garantia Constitucional. 30 Duplo Grau de Jurisdição e o Pacto de São Jose da Costa Rica. 40 Atual Status Normativo dos Direitos e Garantias Decorrentes dos Tratados Internacionais de Direitos Humanos. 50 Entendimento Firmado pelo STF na Ação Penal no 470/MG. 6 Análise Crítica da Decisão de Indeferimento do Pedido de Desmembramento na Ação Penal no 470/MG. 70 Caso "Barreto Leiva Versus Estado da Venezuela": Posição da Corte Interamericana de Direitos Humanos. 8 Conclusão. 9 Referências. 


\section{INTRODUÇÃO}

O julgamento da ação penal no 470/MG, mais conhecida como "Caso Mensaláo", trouxe para o debate jurídico nacional questôes variadas de alta complexidade. Entre elas, merece destaque a garantia do duplo grau de jurisdição, questão objeto de debate durante o referido julgamento e que perpassa pela análise da Constituição Federal, do Pacto de São José da Costa Rica e do Código de Processo Penal.

$\mathrm{Na}$ citada ação penal originária constavam 38 denunciados, dos quais apenas 3, em razão de ocuparem cargo de deputado federal, faziam jus à prerrogativa do foro privilegiado, prevista na Constituição Federal e que permite o julgamento perante o Supremo Tribunal Federal. Os demais denunciados, apesar de não possuírem foro por prerrogativa de função, também foram julgados em única instância pela Corte Máxima, em razão de um dispositivo previsto no Código de Processo Penal, o qual determina a uniáo dos processos nos casos em que restar caracterizada conexão ou continência entre os fatos apontados pelo órgáo de acusação. Nesta circunstância, parece mais evidente o desrespeito à garantia do duplo grau de jurisdição e, em ricochete, também ao princípio do juiz natural, garantia prevista na Constituiçấo Federal e tratados internacionais de direitos humanos que o Brasil ratificou.

Seguindo o entendimento de que não viola a garantia do duplo grau de jurisdição o julgamento efetivado pelo Tribunal Máximo de cada país, o Supremo Tribunal Federal, por maioria (nove votos contra e dois a favor), rejeitou o pedido formulado pelo advogado Márcio Thomaz Bastos, no sentido de que fosse efetivado o desmembramento do processo, o que permitiu que todos os réus do "Mensalão" (os que tinham e os que não tinham foro por prerrogativa de função) fossem julgados por aquela Corte.

O objetivo deste ensaio, portanto, gravita à orbita da necessidade de analisar o teor da fundamentaçáo do acordáo prolatado na ação penal n. 470/MG, no aspecto pertinente ao duplo grau de jurisdição e sua compatibilidade aos dispositivos do Pacto de Sáo José da Costa Rica. 


\section{DUPLO GRAU DE JURISDIÇÃO COMO GARANTIA CONSTITUCIONAL}

Entre os grandes problemas expressos no plano da teoria política destaca-se o que diz respeito à existência de instrumentos e mecanismos efetivos de preservação do cidadão diante do poder estatal, com proteção às liberdades. As imposições da classe burguesa com origem no século 19 determinaram a substituição do modelo clientelista e patrimonialista próprio do regime feudal, passando-se para uma conformação da impessoalidade da dominação, numa estrutura administrativa burocrática que se assenta na formalidade como elemento fundamental de organização "desse artifício de dominação" e que se desenvolveu por intermédio de governos per leges, sub leges e Estado Constitucional de Direito (CADERMATORI, 1999, p. 81).

A Constituição Brasileira de 1988, promulgada após longo período ditatorial, consagra, em seu artigo $5^{\circ}$, extenso rol de direitos e garantias fundamentais em título específico, cujo Capítulo I aborda os Direitos e Deveres Individuais e Coletivos. Nesse mesmo artigo, a Carta Magna dispóe acerca das garantias constitucionais do processo, vocacionadas para a tutela jurisdicional da liberdade e de outros direitos fundamentais.

Houve ainda expressa menção à garantia do devido processo legal, de modo que o constituinte teve claro propósito no sentido de assegurar a tutela constitucional das liberdades, por intermédio da ampliação do rol dos remédios constitucionais e por meio de minuciosa previsão de princípios que servem de base para esta tutela (PASSOS, 2005, p.56). O intuito do constituinte parece ter sido claro: as garantias constitucionais foram criadas para que os direitos fundamentais previstos na Constituição Federal ou nos tratados internacionais dos quais o Brasil seja signatário possam ser exigidos, vale dizer, para que se possa insurgir contra as violações efetivadas em desacordo com direitos fundamentais. Desse modo, no plano constitucional existem, portanto, os direitos fundamentais e as garantias constitucionais a estes correspondentes, significando estas últimas uma espécie de "escudo da personalidade contra desvio de poder" (BONAVIDES, 2004, p. 564). Observa o constitucionalista português Jorge Miranda: "clássica e bem atual é contraposição dos direitos fundamentais, pela sua natureza, sua estrutura e pela sua função, em direitos propriamente ditos ou direitos e liberdades, por um lado, e garantias, por outro lado" (2012, p. 88). 
Hodiernamente, as garantias constitucionais são interpretadas em duas acepçóes. Em sentido amplo, elas são entendidas como instrumentos que permitem a defesa da própria ordem constitucional e da preservação do Estado de Direito. Em sentido estrito, entende-se que as garantias constituem instrumento de preservação não apenas da ordem constitucional, mas também de proteção dos direitos subjetivos. A relação entre Direito Penal e Direito Processual Penal e os direitos humanos apresenta uma tensão antinômica entre os dois polos. Essa antinomia reside na própria essência do poder punitivo do Estado, o qual atinge, pela sua própria natureza, direitos fundamentais do indivíduo, a começar pela liberdade individual. Por outro lado, o sistema penal exerce também uma função de proteção dos direitos fundamentais, por intermédio da incriminação de comportamentos, num contexto de movimento duplo, para afirmar positivamente valores e atribuir sentido delitivo a sua transgressão. A harmonização e busca do ponto de equilíbrio entre a segurança social e os direitos individuais apresenta-se como uma das mais complexas tarefas no estabelecimento do conteúdo e da legitimação da intervenção jurídico-penal (DELMAS-MARTY, 2004, p. 23).

A expressão "Estado Democrático de Direito", por sua vez, representa algo novo, que introduz um componente revolucionário e transformador ao Estado tradicional, vale dizer, a defesa do modelo estatal que, de forma essencial, tende a afastar a inclinação humana ao autoritarismo e concentração de poder. Imanentes ao regime democrático existem alguns postulados essenciais, a exemplo da garantia dos direitos fundamentais do homem, a valorizaçáo do indivíduo e da personalidade integrada e o compromisso entre ideias opostas, para uma solução pacífica (GARCIA, 1997, p. 43).

Os constitucionalistas reconhecem a existência de garantias constitucionais de cunho processual, entre as quais merecem destaque a cláusula do devido processo legal, da ampla defesa, do contraditório, da motivação das decisóes judiciais, da proibição da prova ilícita, do juiz natural e da duração razoável do processo.

O duplo grau de jurisdição, por sua vez, não está previsto explicitamente na Constituição Federal de 1988, tampouco esteve previsto nas outras Constituiçôes republicanas. Em verdade, somente a Constituição de 1824 fez expressa menção ao duplo grau de jurisdição. Por tal pretexto, não é unânime na doutrina o entendimento de que o duplo grau seja uma garantia constitucional. 
Registre-se o fato de que esta controvérsia já fora objeto de análise por parte do Supremo Tribunal Federal, no ano 2000, portanto, em momento anterior à promulgação da Emenda Constitucional $n^{\circ} 45$. Naquela ocasiáo, nos autos do recurso de habeas corpus $\mathrm{n}^{\circ} 79.785$, os ministros da Corte Suprema acompanharam o entendimento firmado pelo ministro Sepúlveda Pertence:

EMENTA: I. Duplo grau de jurisdição no Direito Brasileiro, à luz da Constituição e da Convenção Americana de Direitos Humanos. 1. Para corresponder à eficácia instrumental que lhe costuma ser atribuída, o duplo grau de jurisdição há de ser concebido, à moda clássica, com seus dois caracteres específicos: a possibilidade de um reexame integral da sentença de primeiro grau e que esse reexame seja confiado a órgáo diverso do que a proferiu e de hierarquia superior na ordem judiciaria. 2. Com esse sentido próprio - sem concessóes que o desnaturem - não é possível, sob as sucessivas Constituiçôes da República, erigir o duplo grau de jurisdiçấo em princípio e garantia constitucional, tantas são as previsóes, na própria Lei Fundamental, do julgamento de única instância ordinária, já na área cível, particularmente, na área penal (...)

$\mathrm{O}$ entendimento firmado não está imune a críticas, isto porque negar o caráter normativo a um conceito pressupóe argumentos de outra ordem, a exemplo da falta de coerência sistemática ou deontológica, o que não parece ser o caso. Com efeito, tal como as previsóes de julgamento por instância única existem restriçóes a outros direitos fundamentais na própria Carta Magna. Nesse sentido, a afirmação de que há contradição entre a previsão de alguns julgamentos em instância única pela Constituição não é argumento satisfatório, haja vista o próprio caráter flexível dos princípios (BRITO; FABRETTI; LIMA, 2013, p. 97).

Ademais, o argumento da previsão difusa de outras exceçôes pode ser utilizado tanto para conceder quanto para negar o caráter de direito ou garantia fundamental, na medida em que, na organização dos Tribunais superiores, em muitos casos, existe a previsão de recursos ordinários, o que representa a própria essência do duplo grau (BRITO; FABRETTI; LIMA, 2013, p.98). 
Por fim, sob este aspecto, deve ser mencionado o fato de que houve mudança de entendimento do Supremo Tribunal Federal em relação ao caráter normativo das regras do Pacto de São José da Costa Rica, durante o julgamento do Recurso Extraordinário $n^{\circ} 466.343$, julgado esse posterior ao acórdáo proferido quando do julgamento do recurso de habeas corpus 79.785 .

\section{DUPLO GRAU DE JURISDIÇÃO E $O$ PACTO DE SÃO JOSÉ DA COSTA RICA}

Apesar de não estar expressamente prevista no Código de Processo Penal, tampouco na Constituição Federal de 1988, a garantia do duplo grau de jurisdição deriva diretamente da cláusula do devido processo legal, o que já seria o bastante para o reconhecimento do seu status de garantia constitucional. Além disso, esta garantia está expressamente prevista no artigo $8^{\circ}, 2$, “h”, do Pacto de São José da Costa Rica, in verbis:

Artigo $8 .^{\circ}-$ Garantias Judiciais.

2. Toda pessoa acusada de um delito tem o direito que se presuma sua inocência, enquanto não for legalmente comprovada sua culpa. Durante o processo, toda pessoa tem direito, em plena igualdade, às seguintes garantias mínimas:

h) direito de recorrer da sentença a juiz ou tribunal superior.

O reconhecimento dessa cláusula no Pacto de São José da Costa Rica parte do reconhecimento da absoluta necessidade de controle dos julgados, em razão da inevitável falibilidade humana e das implicaçóes que ela acarreta nas decisóes judiciais. Os recursos, portanto, são vias idôneas para reparar os erros cometidos e lograr a legitimidade e a legalidade das decisóes emanadas do poder Judiciário. Desse modo, com a Convenção Americana Sobre Direitos Humanos e o Pacto Internacional de Direitos Civis e Políticos, o fundamento dos recursos contra decisóes condenatórias adquiriram a conotação de garantia judicial do condenado no sentido de que o julgado será revisado por órgão superior (LIBERATORE, 2001, p. 340). 
Desse modo, uma vez adotada pelo ordenamento jurídico brasileiro a Convenção Americana de Direitos Humanos, restou enriquecida a cláusula do devido processo legal, ante a perspectiva de reconhecimento da chamada garantia de proteção judicial, que implica o reconhecimento do dever do Estado de assegurar o direito ao recurso contra qualquer ato que viole direitos fundamentais do cidadão.

Por sua vez, a discussão acerca do status constitucional da cláusula do duplo grau de jurisdição adquiriu novos ares com a previsão do $₫ 2^{\circ}$ do artigo $5^{\circ}$ da Constituição Federal de 1988, o qual dispóe que os direitos e garantias expressos não excluem outros decorrentes do regime e dos princípios por ela adotados ou dos " tratados internacionais em que a República Federativa do Brasil seja parte" (BRITO; FABRETTI; LIMA, 2013, p. 99). Diante desse dispositivo, alguns autores passaram a firmar o entendimento de que o duplo grau adquirira o status de garantia constitucional por via reflexa (LOPES JÚNIOR, 2013, p. 1.167).

\section{ATUAL STATUS NORMATIVO DOS DIREITOS E GARANTIAS DECORRENTES DOS TRATADOS INTERNACIONAIS DE DIREITOS HUMANOS}

Não obstante a alteração efetivada no artigo $5^{\circ}$, $\$ 2$, da Constituição Federal de 1988, o Supremo Tribunal Federal, inicialmente, manteve o posicionamento original, no sentido de que os tratados internacionais possuíam o mesmo nível hierárquico das leis ordinárias. A mudança de entendimento em relação ao status normativo dos direitos previstos nos tratados internacionais adveio do julgamento do Recurso Extraordinário n ${ }^{\circ} 466.343$, ocasiāo em que o Pleno da Suprema Corte debateu a possibilidade de prisão do depositário infiel, prevista no artigo $5^{\circ}$, LXVIII, da Constituição Federal, em razão do artigo $7^{\circ}$, item 7 , da Convenção Americana de Direitos Humanos, uma vez que, enquanto o primeiro dispositivo previa a prisão do depositário infiel, o segundo proibia a prisão em decorrência de dívidas. Durante vários anos o Supremo Tribunal Federal considerou que a norma constitucional não tinha sido afetada pela ratificação da citada Convenção, no ano de 1992, de modo que a validade das normas infraconstitucionais que regulavam essa modalidade de prisão foi mantida (MAUÉS, 2013, p. 28). 
Após intenso debate, por maioria de votos, o Pleno decidiu que o referido tratado internacional, assim como as demais convençôes de direitos humanos celebradas antes de 2004, cujo quórum de aprovação não atingisse aquele reservado às emendas constitucionais, teriam caráter de norma supralegal, contudo, infraconstitucional, acompanhando, assim, a tese sustentada pelo ministro Gilmar Mendes:

EMENTA: PRISÃO CIVIL. Depositário Infiel. Alienação fiduciária. Decretação da Medida Coercitiva. Inadmissibilidade absoluta. Insubsistência da previsão constitucional e das normas subalternas. Interpretação do artigo $5^{\circ}$, inciso LXVII e $\$ \$ 1^{\circ}, 2^{\circ}$ e $3^{\circ}$, da Constituição Federal, à luz do art. $7^{\circ}$, $\$$, da Convenção Americana de Direitos Humanos (Pacto de San José da Costa Rica). Recurso Improvido. Julgamento conjunto do RE $n^{\circ} 349.703$ e dos HCs ${ }^{\circ}$ 87.585 e nº 92.566 . È ilícita a prisão civil de depositário infiel, qualquer que seja a modalidade de depósito.

Sem embargo do entendimento firmado pelo Supremo Tribunal Federal, a doutrina não é unânime em relação ao status normativo dos dispositivos previstos em tratados internacionais de direitos humanos. Há um forte setor na doutrina que, há anos, defende a ideia de que os tratados de direitos humanos, em razão do artigo $5^{\circ}, \$ 2$ da Carta Magna, possuem status de norma constitucional. Segundo esta corrente, referida norma constitucional caracteriza uma cláusula aberta de recepção de outros direitos humanos enunciados em documentos internacionais. Nesse sentido, por exemplo, Flávia Piovesan:

Enfatize-se que, se à luz da Carta Magna de 1988, os demais tratados internacionais têm força hierárquica infraconstitucional, nos termos do art. 102, III, $\mathrm{b}$, do texto (que admite o cabimento de recurso extraordinário de decisão que declarar a inconstitucionalidade de tratado), os direitos enunciados em tratados internacionais de proteção dos direitos humanos detêm hierarquia de norma constitucional. Este tratamento jurídico diferenciado se justifica, na medida em que os tratados internacionais de direitos humanos apresentam um caráter especial, distinguindo-se dos tratados internacionais comuns (2005, p. 44).

No mesmo sentido, Grinover, Cintra e Dinamarco acentuam que as normas de garantia da Convençáo Interamericana de Direitos Humanos guardam, no plano interno, o mesmo nível hierárquico das regras do artigo $5^{\circ}$, da Constituiçáo Federal 
(2008, p. 40). Nesta senda, Mazzuolli explica que, se a própria Carta Magna determina que os direitos e garantias nela elencados não excluem outros decorrentes dos tratados internacionais em que a República Federativa seja parte, significa isso que o intuito do legislador constituinte fora o de autorizar a absorção desses direitos e garantias de cunho internacional constantes desses instrumentos ratificados pelo Brasil, como se estivessem efetivamente escritos no corpo da Constituição (2013a, p. 34). De outro modo, autores contrários a esse entendimento aduzem que, se após a alteração constitucional o $\$ 3^{\circ}$ confere o status de emenda constitucional somente aos tratados aprovados mediante quórum especial nas duas casas, antes, quando a aprovaçáo era feita apenas por decreto, sem passar pelas duas casas e sem quórum qualificado, por certo, não poderia ter o mesmo status de norma constitucional, senão a alteração seria inócua. Desse modo, a tese da supremacia dos tratados é rejeitada com recorrência, sob o argumento de que anularia a própria possibilidade do controle de constitucionalidade desses diplomas internacionais (MENDES; COELHO; BRANCO, 2008, p. 694).

Mello, por sua vez, sustenta, em posição minoritária, a supremacia dos tratados internacionais de direitos humanos em relação à Constituição Federal. Nesse sentido, as normas constitucionais não teriam poderes revogatórios em relação às normas de Direito Internacional, de modo que nem mesmo o poder constituinte originário teria preponderância capaz de suprimir regras internacionais de direitos humanos ratificados pelo Estado Brasileiro (1999, p. 25). Deve ser registrado, no entanto, a ideia de que, apesar da atual previsão de um bloco de constitucionalidade, o Supremo Tribunal Federal assume posição bastante cautelosa e conservadora em relação ao tema (LOPES, 2009, p. 54).

\section{ENTENDIMENTO FIRMADO PELO STF NA AÇÃO PENAL N 470/MG}

O tema referente ao status normativo da garantia do duplo grau de jurisdição voltou à tona no âmbito do Supremo Tribunal Federal durante o julgamento da ação penal n 470/MG, mais conhecida como "Caso Mensalâo". Na oportunidade, apenas 3 dos 38 denunciados originariamente possuíam o foro por prerrogativa de função. A questão fora suscitada pelo advogado Márcio Thomaz Bastos, tendo a Suprema Corte decidido pelo indeferimento do pedido de desmembramento do feito: 
EMENTA: Primeira Preliminar. Incompetência. Foro por prerrogativa de função. Desmembramento indeferido. Preclusão. Rejeitada a preliminar de incompetência do STF para julgar a acusação formulada contra os 34 (trinta e quatro) acusados que não gozam de prerrogativa de foro. Matéria preclusa, tendo em vista que na sessão plenária realizada no dia 6.12.06, decidiu-se, por votação majoritária, pela necessidade de manter-se um processo único, perante o Supremo Tribunal Federal.

Na ocasião, a Corte Suprema decidiu pela preponderância das normas processuais de conexão e continência previstas no Código de Processo Penal, ${ }^{1}$ em detrimento do preceito previsto na Convenção Americana de Direitos Humanos, de modo que todos os acusados, inclusive aqueles que náo possuíam cargos públicos, foram julgados em instância única pelo Supremo Tribunal Federal.

O ministro Joaquim Barbosa sustentou, em seu voto, o fato de o processo atinente à referida ação penal tramitar fazia cinco anos na Corte, além do conteúdo da súmula n. 714 do Supremo Tribunal Federal. ${ }^{2}$ Além disso, afirmou a existência de outros julgados nos quais os ministros votaram pelo indeferimento do desmembramento (acórdão na AP 470/MG, fls. 51.667).

${ }^{1}$ Art. 78. Na determinação da competência por conexão ou continência, serão observadas as seguintes regras:

I - no concurso entre a competência do júri e a de outro órgão da jurisdição comum, prevalecerá a competência do júri;

Il - no concurso de jurisdiçóes da mesma categoria; (Redaçáo dada pela Lei no 263, de 23.2.1948)

a) preponderará a do lugar da infração, à qual for cominada a pena mais grave (Redação dada pela Lei no 263, de 23.2.1948)

b) prevalecerá a do lugar em que houver ocorrido o maior número de infraçôes, se as respectivas penas forem de igual gravidade; (Redação dada pela Lei no 263, de 23.2.1948)

c) firmar-se-á a competência pela prevenção, nos outros casos; (Redação dada pela Lei no 263, de 23.2.1948)

III - no concurso de jurisdições de diversas categorias, predominará a de maior graduaçấo; (Redação dada pela Lei $n^{\circ} 263$, de 23.2.1948)

IV - no concurso entre a jurisdição comum e a especial, prevalecerá esta (Redação dada pela Lei ${ }^{\circ}$ 263, de 23.2.1948).

2 Não viola as garantias do juiz natural, da ampla defesa e do devido processo legal a atração por continência ou conexão do processo do corréu ao foro por prerrogativa de função de um dos denunciados. 
Em voto divergente, o ministro Ricardo Lewandowski alertou para a impossibilidade de reconhecimento da preclusão no presente caso, uma vez que se trata de matéria de ordem pública. Acentuou ainda que o Supremo Tribunal Federal, em diversas ocasióes determina o desmembramento das açôes penais (acórdão na $\mathrm{AP}$ 470/MG, fls. 51.680). Nesse sentido, argumenta o eminente ministro:

Insisto, pois, que o desmembramento de inquéritos e de açôes penais tornou-se prática corriqueira nesta Corte, sendo as respectivas decisôes, inclusive, cada vez mais levadas a efeito monocraticamente pelos seus integrantes. Eis aqui alguns exemplos: Inq 2.757/MG e Inq 2.601/RJ, Rel. Min. Celso de Mello; Inq 2.652/ PR, Rel. Min. Dias Toffoli; Inq 2.280/MG, Rel. Min. Joaquim Barbosa; Inq 2.486/AC e Inq 2.091/RR, Rel. Min. Ayres Britto; Inq 2.239/PI e Inq 1.567/ CD, Rel. Min. Sepúlveda Pertence. Constata-se, pois, que esta Suprema Corte, na grande maioria das vezes em que foi chamada a pronunciar-se sobre o tema, tem autorizado o desmembramento, sendo essa prática, hoje, repito, aplicada rotineiramente e de forma monocrática. Tais decisões, ademais, vêm sendo sistematicamente confirmadas pelo Plenário, nos raros agravos regimentais contra elas manejados. Não posso deixar de registrar, nesse passo, que é objeto da maior perplexidade, por parte daqueles que acompanham os trabalhos desta Suprema Corte, o fato de que, nalgumas situaçóes em tudo semelhantes à presente, tenha ela deferido o desmembramento dos feitos, contrariamente ao que ocorreu no presente processo. Como se percebe, pelos diversos precedentes antes mencionados, as raras decisóes no sentido do não desmembramento dos feitos são, em geral, de natureza casuística, repousando, quase sempre, em argumentos de ordem pragmática, quando náo baseados em uma ótica eminentemente subjetiva. Tal constataçáo impede que se delimite conceitualmente os casos em que o desmembramento deve ou não ocorrer, levando a um indesejável casuísmo ou reprovável voluntarismo decisório (Acórdáo na AP 470/MG, fls. 51688).

Ainda no referido voto divergente, o ministro Ricardo Lewandowski também alertou para o respeito à garantia do juiz natural e do duplo grau de jurisdição:

Outro aspecto de extrema importância a ser observado é que o julgamento de pessoas que não possuem prerrogativa de foro no Supremo Tribunal Federal, além de vulnerar o princípio do juiz natural - na medida em que impede que o magistrado constitucionalmente escolhido aprecie a causa, viola também o princípio do duplo grau de jurisdição. Ademais, como se sabe, a nossa Consti- 
tuição preconiza, em seu art. $5^{\circ}, \S 2^{\circ}$, que os direitos e garantias nela expressos “ não excluem outros decorrentes do regime e dos princípios por ela adotados, ou dos tratados internacionais em que a República Federativa do Brasil seja parte ”. Por esse motivo, há muito venho me manifestando no sentido de que o direito ao duplo grau de jurisdição tem assento constitucional, como, por exemplo, no julgamento do HC $88.420 / \mathrm{PR}$, de minha relatoria. Ainda que não se adote a tese segundo a qual todos os direitos fundamentais previstos em tratados internacionais têm hierarquia constitucional, eis que tal depende da forma como são internalizados, lembro que esta Corte posicionou-se no sentido de que eles possuem, no mínimo, uma natureza supralegal, segundo definição do Plenário levada a efeito no julgamento dos Recursos Extraordinários 394.703/ RS, Rel. Min. Ayres Britto, e 466.343/SP, Rel. Min. Cezar Peluso. Naqueles julgamentos entendeu-se insubsistente a prisão civil do depositário infiel, prevista na legislação ordinária, em face da adesão do Brasil, sem qualquer reserva, no ano de 1992, ao Pacto Internacional dos Direitos Civis e Políticos (art. 11) e à Convenção Americana sobre Direitos Humanos. Desse modo, não vejo como seja possível admitir-se que a interpretação de normas infraconstitucionais, notadamente daquelas que integram o Código de Processo Penal - instrumento cuja finalidade última é proteger o jus libertatis do acusado diante do jus puniendi estatal, derrogue a competência constitucional estrita fixada pela Carta Magna aos diversos órgáos judicantes e, mais, permita malferir o princípio do duplo grau de jurisdição, nela abrigado e mais uma vez acolhido, de livre e espontânea vontade, pelo Brasil, após a promulgaçáo daquela, quando aderiu sem reservas ao Pacto de San José da Costa Rica (acórdão na AP 470/MG, fls. 51703).

Em verdade, e conforme será detalhado no próximo tópico, em nenhuma hipótese seria cabível a prevalência de norma do Código de Processo Penal em relação ao direito fundamental garantido pela norma de direito humano internacional.

\section{ANÁLISE CRÍTICA DA DECISÃO DE INDEFERIMENTO DO PEDIDO DE DESMEMBRAMENTO NA AÇÃO PENAL N ${ }^{\circ}$ 470/MG}

No julgamento da ação penal objeto deste estudo, o Supremo Tribunal Federal decidiu preponderar as normas processuais de conexão e continência, em detrimento do dispositivo atinente ao duplo grau de jurisdição, previsto na 
Convenção Americana de Direitos Humanos, permitindo que todos os acusados, especialmente os que náo tinham foro por prerrogativa de função, fossem julgados em instância única por aquela Corte. Como é cediço, a conexão e a continência são modalidades de prorrogação da competência as quais provocam a unidade de processo e julgamento e que estão previstas no Código de Processo Penal (GRINOVER; CINTRA; DINAMARCO, 2008, p. 148).

No caso em tela, o Supremo Tribunal Federal, com supedâneo em interpretação literal, aplicou o dispositivo previsto no artigo 78, III, do Código de Processo Penal, o qual faz prevalecer, no concurso de jurisdiçóes de categorias diversas, a de maior graduação. Por outro lado, o próprio Código de Processo Penal estipula exceçôes à regra de unidade de julgamento dos processos em casos de conexão e continência, especialmente nos artigos 79 e $80 .^{3}$

Merece destaque a inteligência do dispositivo previsto no artigo 80 do Código de Processo Penal, na medida em que o julgamento conjunto de agentes acusados da prática de ilícitos penais que tenham status processual distinto não é obrigatório, uma vez que o Tribunal ou juiz poderá considerar conveniente a separação.

O Supremo Tribunal Federal, por sua vez, e como bem alertou o ministro Ricardo Lewandowski em seu voto (acórdáo na AP 470/MG, fls. 51.679), tendo em vista o disposto no artigo 80 do Código de Processo Penal, sistematicamente determina o desmembramento de inquéritos e açóes penais que nele tramitam. O desmembramento ocorreu, por exemplo, no Inquérito 517-QO/DF, Rel. min. Octávio Gallotti, julgado em 8/10/1992, ocasião em que o Plenário decidiu, por

\footnotetext{
${ }^{3}$ Art. 79. A conexão e a continência importarão unidade de processo e julgamento, salvo:

I - no concurso entre a jurisdiçăo comum e a militar;

II - no concurso entre a jurisdição comum e a do juízo de menores.

$\$ 1^{\circ}$ Cessará, em qualquer caso, a unidade do processo, se, em relação a algum co-réu, sobrevier o caso previsto no art. 152.

$\$ 2^{\circ} \mathrm{A}$ unidade do processo não importará a do julgamento, se houver corréu foragido que não possa ser julgado à revelia, ou ocorrer a hipótese do art. 461.

Art. 80. Será facultativa a separaçấo dos processos quando as infraçóes tiverem sido praticadas em circunstâncias de tempo ou de lugar diferentes, ou, quando pelo excessivo número de acusados e para náo lhes prolongar a prisão provisória, ou por outro motivo relevante, o juiz reputar conveniente a separação.
} 
unanimidade, que o fato isolado atribuído a determinado deputado federal não apresentava vínculo de conexão com os demais indiciados, o que permitiria o desmembramento do feito, conforme ementa:

Fato isolado, atribuído a deputado federal, sem vínculo de conexão com os imputados aos demais figurantes do inquérito policial (art. 76 do Cod. Proc. Penal). Desmembramento deferido em questão de ordem, a requerimento do ministério público federal.

Também no Inq 336-Agr/TO, Rel. min. Carlos Velloso, cujo julgamento se deu por maioria de votos, entendeu-se que, como apenas 1 dos 60 réus detinha foro por prerrogativa de funçáo, o processo deveria ser desmembrado, uma vez que não se afigurava ponderado permitir a instrução da ação penal naquela Corte, conforme ementa a seguir:

CONSTITUCIONAL. PROCESSUAL PENAL. PENAL. CRIME DE QUADRILHA. FORO POR PRERROGATIVA DE FUNÇÃO. SEPARAÇÃO DOS PROCESSOS. CPP, art. 80. NÚMERO EXCESSIVO DE ACUSADOS. PREJUÍZO DA DEFESA: INEXISTÊNCIA. I. - O fato de um dos corréus ser Deputado Federal náo impede o desmembramento do feito com base no art. 80 do Código de Processo Penal. II. - A possibilidade de separação dos processos quando conveniente à instrução penal é aplicável também em relação ao crime de quadrilha ou bando (art. 288 do Código Penal). III. - Agravos não providos.

Em julgado mais recente, realizado no dia 27 de março de 2014, nos autos da Ação Penal n 536, derivada do Inquérito 2.280/MG, sob a relatório do ministro Joaquim Barbosa, instaurado para apurar o caso conhecido por "Mensaláo Tucano", o Supremo Tribunal Federal deferiu o pedido de desmembramento efetivado pela defesa dos acusados. Importante é salientar que os envolvidos foram acusados de atuar com modus operandi muito semelhante ao descrito na Ação Penal n 470/ MG. O pedido da defesa fora acatado conforme está na sequência:

No presente inquérito, apenas o primeiro, dos quinze denunciados, detém a prerrogativa de foro prevista no art. 102, I, b, da Constituição da República. Com efeito, como destacou a Procuradoria-Geral da República, a hipótese é de conexáo e continência, enquadrando-se nos termos dos artigos 76 a 79 do 
Código de Processo Penal. Este Tribunal admite a prorrogação da sua competência para processar e julgar não só o detentor da prerrogativa de foro como também seus corréus não detentores de foro privilegiado, com base nos referidos dispositivos legais (...).

Contudo, havendo algum motivo relevante, entende-se que os processos podem ser separados, com base no que dispóe o art. 80 do Código de Processo Penal (...):

No caso em análise, o motivo relevante que, a meu ver, autoriza o desmembramento, é o número excessivo de acusados, dos quais somente 1 (um) - o Senador da República Eduardo Azeredo (PSDB/MG) - detém prerrogativa de foro perante o Supremo Tribunal Federal. Ademais, a data em que os fatos supostamente teriam ocorrido - de julho a dezembro de 1998 - também recomenda o desmembramento, tendo em vista a necessidade de máxima celeridade no processamento do feito, observados os demais princípios que regem o processo penal. Diante deste fato, e para maior efetividade destas garantias constitucionais, considero importante acolher o pleito dos acusados no sentido do desmembramento. A manutenção do polo passivo em sua integralidade poderia retardar o andamento do processo e prejudicar a prestação jurisdicional. $\mathrm{O}$ presente Inquérito $\mathrm{n}^{\circ} 2.280$ tem, atualmente, quarenta e dois volumes principais e quarenta e dois apensos, que se multiplicarão ao longo da eventual instruçáo criminal, caso a denúncia seja recebida contra todos os acusados. O Supremo Tribunal Federal possui vários precedentes de açôes e procedimentos criminais com número expressivo de pessoas envolvidas. Em quase todos eles, prevaleceu a racionalidade comandada pelo art. 80 do Código de Processo Penal, o que conduziu ao desmembramento do processo pela Corte. Dentre outros, cito os seguintes precedentes, mencionados também pelos acusados Marcos Valério e Cláudio Mourão.

Como se vê, o inquérito denominado "Mensalão" (atual AP n 470) constitui um caso isolado, em que não se logrou alcançar um consenso quanto ao desmembramento, tendo o Plenário desta Corte, após séria clivagem verificada na votação, decidido por manter os autos com a sua gigantesca configuração de 40 acusados. Já no caso presente, não vislumbro razóes para me afastar da jurisprudência sedimentada do Supremo Tribunal Federal, no sentido de determinar 
o desmembramento do processo em casos como o presente. Ao contrário da Ação Penal n 470, que envolveu 40 acusados e os crimes de peculato, lavagem de dinheiro, formação de quadrilha, corrupção ativa, corrupção passiva, evasão de divisas e gestão fraudulenta de instituição financeira, no presente Inquérito n. 2.280 só há a imputação dos crimes de peculato e lavagem de dinheiro, sem as implicações intersubjetivas dos crimes de formação de quadrilha, corrupção ativa e corrupção passiva. Assim, por não haver, neste inquérito, qualquer excepcionalidade que impeça a aplicação do art. 80 do Código de Processo Penal, defiro o pedido formulado pelos réus Eduardo Guedes, Marcos Valério e Cláudio Mourão e determino o desmembramento do processo, devendo permanecer perante esta Corte apenas o processo e julgamento dos crimes imputados ao senador Eduardo Azeredo.

Desse modo, resta clarividente ante diversos precedentes mencionados que o Supremo Tribunal Federal tem, de forma sistemática, deferido os pedidos de desmembramento das açóes penais em tramitaçáo naquela Corte, com base na própria inteligência do artigo 80 do Código de Processo Penal. O entendimento firmado na Ação Penal n 470/MG, portanto, fora endossado com base em razóes de ordem puramente pragmáticas, o que dificulta estabelecer uma ordem de razóes que delimite as hipóteses em que o desmembramento deve ou não ocorrer.

Afora o casuísmo das razóes que levaram à negação de desmembramento na Ação Penal n 470/MG, o Supremo Tribunal Federal desconsiderou o entendimento firmado durante o julgamento do Recurso Extraordinário n. 466.343, no qual restou consolidado o entendimento de que as normas advindas da Convençáo Americana de Direitos Humanos têm status de regra infraconstitucional, porém supralegal. Nessa perspectiva, jamais as regras previstas no Código de Processo Penal, atinentes aos critérios de conexão e continência, poderiam suplantar a garantia do duplo grau de jurisdição prevista no pacto internacional de direitos humanos.

Ainda que não houvesse o reconhecimento da tese de supralegalidade, deve ser ressaltado o fato de que o nível hierárquico dos tratados internacionais de direitos humanos, na ordem interna, não é a única variável a condicionar a sua utilização para interpretar a Constituição e a legislação infraconstitucional, uma vez que em muitos países, inclusive os que não reconhecem o nível constitucional desses tratados, existe consenso no sentido de interpretar as disposiçóes constitucionais 
e legais em harmonia com os instrumentos internacionais de reconhecimento dos direitos humanos (MAUÉS, 2013, p. 41). Nesse mesmo sentido, o reconhecimento do critério da norma mais favorável às vítimas de violaçóes de direitos humanos também reforça a necessidade de interpretação das leis em consonância com os tratados internacionais (MAZZUOLI, 2013b).

Sob tal óptica, não seria sequer necessário afastar definitivamente as disposiçôes dos artigos 78 e 79 do Código de Processo Penal, mas apenas interpretar os dispositivos, de modo que a sua aplicação não pudesse ser efetivada em hipóteses nas quais restasse prejudicada a garantia do duplo grau de jurisdiçáo. Vale salientar que no julgamento do Recurso Extraordinário n 466.343, ante a supralegalidade do Pacto de Sáo José da Costa Rica, o Supremo Tribunal Federal esvaziou a força normativa do dispositivo constitucional que prevê a prisão do depositário infiel, ao proibir que o legislador infraconstitucional decidisse sobre a matéria (MAUÉS, 2013, p. 33). Tal situação torna o entendimento firmado na Ação Penal $\mathbf{n}^{\circ} 470 /$ MG ainda mais incoerente, pois nesse caso não seria necessário esvaziar o conteúdo normativo infraconstitucional dos artigos 78 e 79 do Código de Processo Penal, mas apenas interpretá-los de acordo com os dispositivos da Convenção Americana de Direitos Humanos.

\section{CASO "BARRETO LEIVA VERSUS ESTADO DA VENEZUELA": Posição da Corte Interamericana de Direitos Humanos}

A Corte Interamericana de Direitos Humanos já se manifestou acerca da garantia do duplo grau de jurisdição e da impossibilidade das normas sobre conexão e continência preponderarem em relação à primeira, especificamente no Caso Barreto Leiva Vs. Venezuela, julgado pela Corte em 17 de novembro de 2009, ocasiáo em que o Tribunal da Organização dos Estados Americanos entendeu que a Venezuela violou o direito ao duplo grau de jurisdição ao não ensejar ao senhor Barreto Leiva o direito de apelar para um Tribunal superior.

Nesse caso, o réu Oscar Enrique Barreto Leiva, ex-diretor geral setorial de administração e serviços do Ministério da Secretaria da Presidência da Venezuela fora processado, julgado e condenado em instância única, em conjunto com o 
ex-presidente venezuelano Carlos Andrés Pérez e outras autoridades. Em outras palavras, a Corte Interamericana entendeu que o réu não dispôs, em consequência da conexáo, da possibilidade de impugnar a sentença condenatória, o que viola frontalmente a garantia do duplo grau prevista (sem qualquer ressalva) na Convençáo Americana sobre Direitos Humanos (MAZZUOLI, 2013a, p. 32). ${ }^{4}$

Apesar de a Corte Interamericana não possuir competência para revisar penas, pois não se manifesta sobre temas que envolvem um processo penal concluído em um dos Estados-partes, o precedente do Caso Barreto Leiva coincide perfeitamente com a situação dos réus condenados na Ação Penal n 470, isto porque foram impedidos de recorrer da sentença condenatória para outro Tribunal interno, em desrespeito à regra internacional do duplo grau que o Estado brasileiro aceitou e se comprometeu a efetivar.

Desse modo, na perspectiva do julgamento semelhante já firmado pela Corte Interamericana de Direitos Humanos, o Supremo Tribunal Federal deveria ter desmembrado o processo do "mensalão" ao menos para os réus que não detinham, à época do julgamento, foro por prerrogativa de função, e assim não procedeu. Com isto, violou uma regra de Direito Internacional prevista na Convenção Americana sobre Direitos Humanos de 1969, conhecida como Pacto de San José da Costa Rica, tratado internacional de direitos humanos que o Brasil ratificou em 1992.

\section{CONCLUSÃO}

Houve relevante modificação no status normativo dos direitos humanos objeto de reconhecimento nos tratados internacionais diante da alteração constitucional constante do artigo $5^{\circ}, \$ 2$ da Carta Magna. O próprio Supremo Tribunal Federal reconheceu a natureza jurídica da supralegalidade às normas previstas na Convenção Americana de Direitos Humanos, ratificada pelo Brasil no ano de 1992.

\footnotetext{
4 A Justiça Italiana inicialmente negou o pedido de extradição do ex-diretor do Banco do Brasil Henrique Pizzolato, condenado na Ação Penal n ${ }^{\circ}$ 470/MG, dentre outros argumentos, em razão de não ter sido observado o direito universal ao duplo grau de jurisdição. Posteriormente, o pedido de extradição fora acatado. Disponível em: <www.brasil47.com.br>. Acesso em: 20 fev. 2016.
} 
O entendimento firmado no julgamento da Ação Penal n 470/MG, no entanto, acerca do pedido de desmembramento do feito em relação aos réus que não tinham foro por prerrogativa de função entra em choque com a garantia do duplo grau de jurisdição, definitivamente reconhecida no Pacto de São José da Costa Rica. Tal incoerência torna-se ainda mais gritante no que toca à atitude do Supremo Tribunal Federal em reconhecer a relevância dos tratados internacionais de direitos humanos em outros julgados, a exemplo do Recurso Extraordinário $n^{\circ} 466.343$, o que denota grande casuísmo da Corte no concernente à aplicação desses dispositivos. Ainda que não houvesse reconhecimento da supralegalidade dos tratados, atualmente, existe consenso em grande parte das Cortes constitucionais, no sentido de interpretar as disposiçóes constitucionais e legais em harmonia com os instrumentos internacionais de reconhecimento dos direitos humanos. No caso em tela, não seria sequer necessário paralisar os dispositivos do Código de Processo Penal, mas apenas interpretá-los de acordo com o Pacto de São José da Costa Rica, de modo a afastar a incidência dos primeiros sempre que restasse prejudicada a cláusula do duplo grau.

$\mathrm{Na}$ mesma senda, restou devidamente constatada a total falta de uniformidade no tratamento dos pedidos de desmembramento de processos criminais oferecidos perante o Supremo Tribunal Federal, uma vez que, em diversos julgados, o referido pedido fora deferido, com base em razóes de ordem essencialmente pragmáticas e subjetivas.

\section{REFERÊNCIAS}

BONAVIDES, Paulo. Curso de Direito Constitucional. 15. ed. São Paulo: Malheiros Editores, 2004 .

BRASIL. Supremo Tribunal Federal. Acórdão recurso de Habeas Corpus n 79.785/RJ. Relator, ministro Sepúlveda Pertence, acórdáo publicado em 22.3.2000. Disponível em: $<$ http.www. stf.jus.br>. Acesso em: 15 fev. 2016.

. Supremo Tribunal Federal. Acórdão em Recurso Extraordinário n ${ }^{\circ} 466.343$. Relator,

ministro Cézar Peluso, acórdão publicado em 3.12.2008. Disponível em: <http.www.stf. jus.br>. Acesso em: 16 fev. 2016. 
. Supremo Tribunal Federal. Acórdão na Ação Penal n 470/MG. Relator, ministro Joaquim Barbosa, acórdão publicado em 22.4.2013. Disponível em: <http.www.stf.jus.br>. Acesso em: 16 fev. 2016.

. Supremo Tribunal Federal. Acórdão no Inq. n 517-00/DF. Relator, ministro Octávio Gallotti, acórdão publicado em 12.6.1992. Disponível em: <http.www.stf.jus.br>. Acesso em: 17 fev. 2016.

. Supremo Tribunal Federal. Acórdão no Inq. n. 336/Agr/TO. Relator, ministro Carlos Velloso, acórdão publicado em 3.5.2004. Disponível em: <http.www.stf.jus.br>. Acesso em: 20 fev. 2016.

. Supremo Tribunal Federal. Acórdão na Ação Penal n. 536 QO/MG. Relator, ministro Roberto Barroso, acórdão publicado em 12.8.2014. Disponível em: <http.www.stf.jus.br>. Acesso em: 20 fev. 2016.

BRITO, Alexis Couto de; FABRETTI, Humberto Barrionuevo; LIMA, Marco Antônio Ferreira. O duplo grau de jurisdição e juiz natural na AP 470/MG. Revista dos Tribunais, ano 102, vol. 933, p. 94-109, jul. 2013.

CADERMATORI, Sérgio. Estado de direito e legitimidade. Porto Alegre: Livraria do Advogado, 1999.

DELMAS-MARTY, Mireille. Os grandes sistemas de politica criminal. Trad. Denise Radanovic Vieira. Barueri: Manole, 2004.

GARCIA, Maria. A democracia e o modelo representativo. In: BASTOS, Celso (Ed.). Democracia, hoje. Um modelo político para o Brasil. Coordenação Maria Garcia. São Paulo: Instituto Brasileiro de Direito Constitucional, 1997.

GRINOVER, Ada Pellegrini. Fundamento político do novo tratamento da revelia. Boletim do IBCCRIM, n. 42, jun./1996. Disponível em: <www.ibccrim.org.br/novo/boletim_2228>. Acesso em: 20 fev. 2016.

GRINOVER, Ada Pelegrini; CINTRA, Antônio Carlos de Araújo; DINAMARCO, Cândido Rangel. Teoria geral do processo. São Paulo: Malheiros, 2008.

LIBERATORE, Gloria Lucrecia. Derecho al Recurso: la impugnación de la sentencia penal como garantia del imputado. Revista de Derecho Penal, Culzoni: Ed. Rubinzal, p. 339-367, 2001.

LOPES, Ana Maria D’Ávila. Bloco de Constitucionalidade e princípios constitucionais: desafios do poder Judiciário. Revista Sequencia, ano XXIX, n. 59, p. 43-60, dez. 2009.

LOPES JÚNIOR, Aury. Direito processual penal. 10. ed. São Paulo: Saraiva, 2013. 
MAUÉS, Antonio Moreira. Supralegalidade dos tratados internacionais de direitos humanos e interpretação constitucional. Revista Internacional de Direitos Humanos, n. 18, p. 27-49, 2013. MAZZUOLI, Valério de Oliveira. O controle jurisdicional da convencionalidade das leis. 3. ed. São Paulo: RT, 2013a.

O caso Mensaláo e a regra do duplo grau de jurisdição. Boletim n. 248, Instituto Brasileiro de Ciências Criminais - IBCCRIM, jul. 2013b.

. A influência dos tratados internacionais de direitos humanos no direito interno. Jus Navigandi, Teresina, ano 4, n. 37, $1^{\circ}$ dez. 1999. Disponível em: <http://jus.com.br/ artigos/1608>. Acesso em: 15 fev. 2016.

MELLO, Celso Duvivier de A. O $\$ 2$ do $5^{\circ}$ da Constituição Federal. In: TORRES, Ricardo Lobo (Org.). Teoria dos direitos fundamentais. Rio de Janeiro: Renovar, 1999.

MENDES, Gilmar Ferreira; COELHO, Inocêncio Mártires; BRANCO, Paulo Gustavo Gonet. Curso de Direito Constitucional. São Paulo: Saraiva, 2008.

MIRANDA, Jorge. Manual de Direito Constitucional. Dos Direitos Fundamentais. 9. ed. Coimbra: Ed. Coimbra, 2012. Tomo IV.

PASSOS, Aline Araújo. Duplo grau de jurisdição: compreensão constitucional do princípio e análise de tema sob a perspectiva das reformas introduzidas no código de processo civil pela Lei 10.352/01. 2005. Tese (Doutorado) - Pontifícia Universidade Católica de São Paulo, 28 nov. 2005.

PIOVESAN, Flávia Cristina. Tratados internacionais dos direitos humanos e a Constituição Federal de 1988. Boletim do IBCCRIM, n. 153, São Paulo: Instituto Brasileiro de Ciências Criminais, ago. 2005. Disponível em: <www.ibccrim.org.br/boletim_artigo/3036>. Acesso em: 20 fev. 2016. 